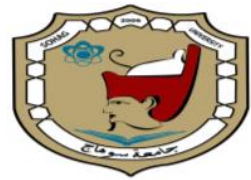

Sohag University

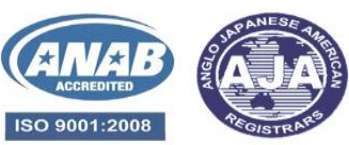

Sohag Medical Journal

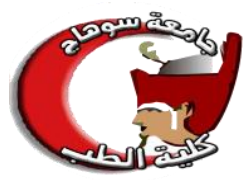

Faculty of Medicine

\title{
Study Of Renovascular Impedance In Type 2 Diabetic Patients with And Without Post viral Hepatitis Cirrhosis
}

\author{
Sara Kasem Abdelaal. Ali Taha Ali . Ashraf A Askar
}

\author{
Department of Internal Medicine, Sohag University Hospital, Sohag, Egypt
}

\begin{abstract}
Background: Renal failure is a common consequence of cirrhotic patients, which is correlated to raised mortality and morbidity. Diabetes is common among cirrhotic patients. Hepatic encephalopathy and hepatocellular carcinoma, ascites, renal dysfunction, and bacterial infections are all possible complications. . T2DM induces liver fibrosis and inflammation, which leads to more severe liver failure and is a strong predictor of death from cirrhosis.

Objective: The goal of this research is to find out more about renovascular resistance in patients with type $2 \mathrm{DM}$ and with liver cirrhosis by using renal Doppler indices (RI and PI ).

Results: The CD-Group (cirrhotic and diabetic patients) and D-Group (diabetic ) patients showed higher resistance indexes (RIs)

than those in the C-Group(cirrhotic patients). Similarly, the CD-Group(cirrhotic and diabetic patients) and D-Group(diabetic ) had significantly greater pulsatility indices than the C-Group. Our findings suggest that, regardless of the severity of the liver illness, hyperglycemia may cause an increase in renal Doppler indices in cirrhotic patients.
\end{abstract}

Conclusion: Diabetes has a significant unfavorable impact on the kidney health of people with liver cirrhosis.

Keywords: liver cirrhosis. Type 2 Diabetes mellitus, renal Doppler indices, renal failure.

\section{Introduction}

Renal failure is a common consequence of patients with liver cirrhosis, which is correlated to raised mortality and morbidity. ${ }^{(1),(2)}$. Acute kidney injury( AKI) affects about 20-50\% of hospitalized patients with cirrhosis $^{(3)}$. A typical pathway of renal failure is the occurrence of active renal

vasoconstriction, which can happen even in the early stages of the disease when routine renal function tests are normal $^{(4)}$.

Because HRS-AKI (Hepatorenal syndrome- acute kidney injury), represents one of the foremost fatal consequences of portal hypertension, the correct classification of AKI is critical and necessitates a specific therapeutic strategy. Despite effective therapy, mortality rates remain around $60 \%$ and higher ${ }^{(5)}$. HRS-AKI is frequently difficult to diagnose

because it is an exclusionary diagnosis As a result, identifying the reason of AKI early on is critical for effective treatment and better outcomes ${ }^{(6)}$. Diabetes is common among cirrhotic patients and is linked to an elevated risk of consequences like hepatic encephalopathy and hepatocellular carcinoma, 
ascites, renal failure, and bacterial infections. ${ }^{(7,8)}$.

\section{Materials and Methods}

Study population:- This research was conducted on (90 individuals) with type 2 diabetes and liver cirrhosis at the Sohag University Hospital's Department of Internal Medicine. And, The Child-Pugh classification ${ }^{(9)}$ and the MELD scoring system (model for endstage liver disease ${ }^{(10)}$. were used to determine the degree of cirrhosis

All participants were divided into 3 groups:

- Diabetic patients (D group) (30 patients) (type $2 \mathrm{DM})$, non-cirrhotic

- Cirrhotic patients (C group) (30 patients ), non-diabetic

- Diabetic(type $2 \mathrm{DM})$ and cirrhotic patients (CD group) (30 patients).

Inclusion Criteria.:

- Patients with Type 2 diabetes with normal renal function (eGFR >90 $(\mathrm{mL} / \mathrm{min} / 1.7 \mathrm{~m} 2)$

- Patients with cirrhosis who have normal renal function (eGFR > 90 $\mathrm{mL} / \mathrm{min} / 1.7 \mathrm{~m} 2$ )

- Post viral hepatitis cirrhotic patients

- All patients will be >40 years old (type 2 diabetic patients)

\section{Exclusion Criteria.}

- Abnormal kidney function (eGFR $<90(\mathrm{~mL} / \mathrm{min} / 1.7 \mathrm{~m} 2)$

- Abnormal urine analysis

- Abdominal ultrasound reveals abnormal kidney size.

- Patients who had encephalopathy, bacterial infection, or gastrointestinal bleeding within the previous two weeks before the research began.

- During the month leading up to the start of the trial, patients were given nephrotoxic or non-steroidal anti-inflammatory medicines.

\section{Methods :}

All patients subjected to full history taking,( Personal history, History of DM, its duration and drug history,
History of hypertension and its duration, History of ischemic heart disease, cerebrovascular disease, diabetic retinopathy.), and full Clinical examination with special concern on signs of hepatic cell failure in cirrhotic patients.

Laboratory Investigation: (Glycated hemoglobin HbA1c, Complete blood count, liver function tests, serology (HCV Abs, HBVS Ag), Serum creatinine, urine analysis, albumin /creatinine ratio ${ }^{(11)}$. The modified diet in renal disease (MDRD) formula is used to compute the estimated glomerular filtration rate(eGFR) as follows: (4-variable) $(\mathrm{mL} / \mathrm{min} / 1.7 \mathrm{~m} 2)$ :

$175 \times \mathrm{SCr}^{-1.154} \times$ age $^{-0.203} \times(0.742$ female $) \times(1.212 \text { black })^{(12)}$

\section{* Renal Doppler measurements: -}

After fasting from food and water for the night, the subjects were investigated. All studies were performed in the radiological department of Sohag university hospital with The same assistant lecturer of radiology used a duplex US instrument (GEP9) with a 3.5- $5 \mathrm{MHz}$ curved probe. Colour Doppler measurements were done, The pulsatility index (PI) and resistance index (RI) were calculated using peak systolic, end-diastolic, and temporal mean flow velocities ( RI)

The PI and RI were estimated by the following formulas: $\mathrm{PI}=$ (peak systolic velocity minus end-diastolic velocity)/mean velocity and RI = (peak systolic velocity minus end-diastolic velocity)/mean velocity.

\section{Statistical analysis}

STATA 14.2 was used to analyze the data ( Stata Statistical Software, Release 14.2, StataCorp LP, College Station, TX). To express quantitative data, the mean, standard deviation, median, and range were employed. To detect comparison in the means of two groups, student t-tests were performed., and To find out the comparison in the 
means of three or more groups, ANOVA was utilized. When data were not normally distributed, When comparing three or more groups, the Kruskal Wallis test was utilized., while the Mann-Whitney test was utilized to make comparisons between two groups. The qualitative data was expressed as a number and a percentage, and the Chi-square test and the Fisher exact test were used to compare them. Pearson and linear regression analysis were done. Odds ratios were obtained from logistic regression analysis. Excel or the STATA application were used to create the graphs. If the P-value was less than 0.05 , the result was judged significant.

\section{Results:-}

A total of 90 participants were enrolled in the study. They were split into three groups:-

1-Diabetic- non-cirrhotic group (30 patients) (D -group )
2-(C- group) cirrhotic - non-diabetic group (30 patients)

3-(CD -group)diabetic and cirrhotic group (30 patients)

As regard gender, there were 42 (46.6\%) female and 48 (53.3\%) male, and the mean age in all patients were $60.96 \pm 7.06$.

- (table 1) as medical history:-In diabetic patients, an insignificant difference $(\mathrm{p}=0.7)$ in medical treatment was detected between (D group) and (CD group) as in (D) group12 patients were on oral therapy while 16 patients were on insulin therapy but in (CD) group 12 patients on oral and 18 on insulin.

-As regard other comorbidities among the three groups. In terms of hypertension, the three groups had no significant differences. but there were significant differences (P-value 0.05) in ischemic heart disease as 8 patients were IHD in (D group) and 2 patients in $(\mathrm{CD})$ group.

(Table 1)Comparison among the three groups of the study as medical history

\begin{tabular}{|c|c|c|c|c|}
\hline Variable & $\begin{array}{c}\text { D-group } \\
\mathbf{N}=\mathbf{3 0}\end{array}$ & $\begin{array}{c}\text { C-group } \\
\mathbf{N}=\mathbf{3 0}\end{array}$ & $\begin{array}{c}\text { CD-group } \\
\mathbf{N}=30\end{array}$ & $\mathbf{P}$ \\
\hline $\begin{array}{l}\text { DM } \\
\text { No } \\
\text { Yes } \\
\end{array}$ & $\begin{array}{c}0 \\
30(100 \%)\end{array}$ & $\begin{array}{c}30(100 \%) \\
0\end{array}$ & $\begin{array}{c}0 \\
30(100 \%)\end{array}$ & - \\
\hline $\begin{array}{l}\text { Treatment of DM } \\
\text { Oral } \\
\text { Insulin }\end{array}$ & $\begin{array}{l}14(46.67 \%) \\
16(53.33 \%)\end{array}$ & & $\begin{array}{l}12(40.00 \%) \\
18(60.00 \%)\end{array}$ & 0.7 \\
\hline $\begin{array}{l}\text { Cirrhosis } \\
\text { No } \\
\text { Yes }\end{array}$ & $\begin{array}{c}30(100 \%) \\
0\end{array}$ & $\begin{array}{c}0 \\
30(100 \%)\end{array}$ & $\begin{array}{c}0 \\
30(100 \%)\end{array}$ & - \\
\hline $\begin{array}{l}\text { Hypertension } \\
\text { No } \\
\text { Yes }\end{array}$ & $\begin{array}{l}18(60.00 \%) \\
12(40.00 \%)\end{array}$ & $\begin{array}{c}26(86.67 \%) \\
4(12.33 \%)\end{array}$ & $\begin{array}{l}14(46.67 \%) \\
16(53.33 \%)\end{array}$ & 0.07 \\
\hline $\begin{array}{l}\text { IHD } \\
\text { No } \\
\text { Yes }\end{array}$ & $\begin{array}{c}22(73.33 \%) \\
8(26.67 \%)\end{array}$ & $\begin{array}{c}30(100 \%) \\
0\end{array}$ & $\begin{array}{c}28(93.00 \%) \\
2(6.67 \%)\end{array}$ & 0.054 \\
\hline $\begin{array}{l}\text { Ascites } \\
\text { No } \\
\text { Yes }\end{array}$ & - & $\begin{array}{l}12(40 \%) \\
18(60 \%)\end{array}$ & $\begin{array}{l}18(60 \%) \\
12(40 \%)\end{array}$ & .06 \\
\hline $\begin{array}{l}\text { Diuretics } \\
\text { No } \\
\text { Yes }\end{array}$ & - & $\begin{array}{l}18 \\
12\end{array}$ & $\begin{array}{c}21 \\
9\end{array}$ & 0.03 \\
\hline
\end{tabular}

- (In table 2) show the comparison among the three groups of the study as regard laboratory finding, as regard se- rum creatinine, there was no difference in serum creatinine levels between the 
(C group) and (CD group), but there was a slight difference in the (D group) slightly reduced than the other groups. The albumin/creatinine ratio was significantly different amongst the three groups, with the (CD group)and (D group) having a higher level than the (C group) as it was( 32.73 \pm 10.70 , $29 \pm 13.79)$ respectively compared with the (C group) (9.98 \pm 5.60$)$. As regards eGFR it was about equal in the $(C D$ group) and (C group )( 94.3 \pm 3 $.6,94.8 \pm 5.02)$ respectively compared to the (D group) (97.6 \pm 7.9$)$, Even though this variation was not statistically significant $(\mathrm{p}=0.6)$. HbA1c was similar in (D group) and (CD group) and it was not statistically significant.

(Table 2)Comparison among the three groups of the study as the regard laboratory finding

\begin{tabular}{|c|c|c|c|c|}
\hline Variable & $\begin{array}{c}\text { D-group } \\
\text { N=30 }\end{array}$ & $\begin{array}{c}\text { C-group } \\
\mathbf{N}=\mathbf{3 0}\end{array}$ & $\begin{array}{c}\text { CD-group } \\
\mathrm{N}=30\end{array}$ & $\mathbf{P}$ \\
\hline $\begin{array}{l}\text { HbA1c \% } \\
\text { Mean } \pm \text { SD } \\
\text { Median (range) }\end{array}$ & $\begin{array}{c}8.07 \pm 1.43 \\
7.5(6.5: 11.6)\end{array}$ & & $\begin{array}{c}8.44 \pm 1.51 \\
8.3(5.5: 11)\end{array}$ & 0.5 \\
\hline $\begin{array}{l}\text { Bilirubin mg/dl } \\
\text { Mean } \pm \text { SD } \\
\text { Median (range) } \\
\end{array}$ & $\begin{array}{c}0.76 \pm 0.20 \\
0.8(0.5: 1.2) \\
\end{array}$ & $\begin{array}{c}3.41 \pm 4.72 \\
2.1(0.4: 19.8) \\
\end{array}$ & $\begin{array}{c}1.20 \pm 1.00 \\
0.8(0.1: 3.1) \\
\end{array}$ & 0.004 \\
\hline $\begin{array}{l}\text { Albumin (g/dl) } \\
\text { Mean } \pm \text { SD } \\
\text { Median (range) }\end{array}$ & $\begin{array}{c}3.35 \pm 0.27 \\
3.5(2.9: 3.7)\end{array}$ & $\begin{array}{l}2.84 \pm 0.60 \\
2.9(2: 3.8)\end{array}$ & $\begin{array}{c}2.81 \pm 0.50 \\
2.9(2.1: 3.5)\end{array}$ & 0.006 \\
\hline $\begin{array}{l}\text { INR } \\
\text { Mean } \pm \text { SD } \\
\text { Median (range) } \\
\end{array}$ & $\begin{array}{c}0.77 \pm 0.19 \\
0.8(0.5: 1.1)\end{array}$ & $\begin{array}{c}1.28 \pm 0.41 \\
1.3(0.6: 1.8)\end{array}$ & $\begin{array}{c}1.21 \pm 0.36 \\
1.2(0.8: 1.9)\end{array}$ & 0.0002 \\
\hline $\begin{array}{l}\text { Albumin/ creatinine } \\
\text { ratio(mg/mmol) } \\
\text { Mean } \pm \text { SD } \\
\text { Median (range) }\end{array}$ & $\begin{array}{c}29 \pm 13.79 \\
33(11: 65)\end{array}$ & $\begin{array}{l}9.98 \pm 5.60 \\
8(2.5: 26)\end{array}$ & $\begin{array}{c}32.73 \pm 10.70 \\
35(15: 55)\end{array}$ & 0.0001 \\
\hline $\begin{array}{l}\text { Serum creatinine } \\
(\mathbf{m g} / \mathbf{d l}) \\
\text { Mean } \pm \text { SD } \\
\text { Median (range) }\end{array}$ & $\begin{array}{c}0.7 \pm 0.12 \\
0.7(0.5: 0.9)\end{array}$ & $\begin{array}{c}0.83 \pm 0.13 \\
0.8(0.6: 1.1)\end{array}$ & $\begin{array}{c}0.87 \pm 0.16 \\
0.9(0.6: 1.1)\end{array}$ & 0.005 \\
\hline $\begin{array}{l}\text { eGFR } \\
\text { Mean } \pm \text { SD } \\
\text { Median (range) }\end{array}$ & $\begin{array}{c}97.6 \pm 7.9 \\
93.7(90.6: 105)\end{array}$ & $\begin{array}{c}94.8 \pm 5.02 \\
93.8(90: 99.82)\end{array}$ & $\begin{array}{c}94.3 \pm 3.6 \\
94(90.7 .: 97.9)\end{array}$ & 0.6 \\
\hline
\end{tabular}

\section{Doppler ultrasound:-}

(In table 3):- In comparison to the CGroup, the RIs were higher in the CDand D-Group patients $(0.75 \pm 0.03$ vs $0.72 \pm 0.06$ vs $0.69 \pm 0.04$ ) (p-value 0.01). similarly, When comparing the CD-Group and D-Group to the CGroup, the PIs were much greater $(1.55 \pm 0.04$ vs. $1.47 \pm 0.09$ vs $1.45 \pm 0$. 11.) (p-value 0.01).

(Table 4) In cirrhotic (C -group), the Child-Pugh Class A patients had a substantially lower PI $(1.43 \pm 0.07)$ $(\mathrm{p}<0.05)$ than the Class B $(1.47 \pm 0.11)$ and Class $C$ patients $(1.52 \pm 0.10)$. The RI yielded similar results $($ Child $\mathrm{A}=$
$0.68 \pm 0.04$; Child $\mathrm{B}=0.70 \pm 0.03$; and Child $\mathrm{C}=0.72 \pm 0.04 ; \mathrm{p}<0.05)$.

-The PI was substantially lower $(p<0.05)$ in the Child Class A patients in the (CD -group), (1.53 \pm 0.05$)$ ) in comparison to Class B( $1.57 \pm 0.01)$ and Class C (1.58 \pm 0.006$)$, The RI yielded similar results (Child $\mathrm{A}=0.72 \pm 0.01$; Child $\mathrm{B}=0.76 \pm 0.02 ; \mathrm{p}<0.05)$.

Between HbA1c and RI, there was a moderately positive connection. There had been a mild positive link between INR and RI, as well as a moderately positive correlation between $\mathrm{Alb} /$ Creat ratio and RI.( figure 1) 
SOHAG MEDICAL JOURNAL Study Of Renovascular Impedance In Type 2 Diabetic Patients with Vol. 25 No. September 32021

Sara Kasem Abdelaal

(Table 3):- Comparison between the three study groups as regards renal Doppler

\begin{tabular}{|l|c|c|c|c|}
\hline Variable & D-group & C-group & CD-group & P \\
& $\mathbf{N = 3 0}$ & $\mathbf{N = 3 0}$ & $\mathbf{N = 3 0}$ & \\
\hline RI & & & & 0.01 \\
Mean \pm SD & $072 \pm 0.06$ & $0.69 \pm 0.04$ & $0.75 \pm 0.03$ & \\
Median (range) & $0.73(0.6: 0.78)$ & $0.69(0.6: 0.73)$ & $0.75(0.7: 0.78)$ & \\
\hline PI & & & & 0.01 \\
Mean \pm SD & $1.47 \pm 0.09$ & $1.45 \pm 0.11$ & $1.55 \pm 0.04$ & \\
Median (range) & $1.54(1.31: 1.59)$ & $1.45(1.3: 1.57)$ & $1.56(1.42: 1.58)$ & \\
\hline
\end{tabular}

RI (resistance index), PI (pulsatility index)

(Table 4):- Doppler findings in cirrhotic patients with and without diabetes $(\mathrm{C}$ Group) (CD-Group)

\begin{tabular}{|c|c|c|c|}
\hline $\begin{array}{l}\text { Child-Pugh class } \\
\text { (C-Group/CD-Group) }\end{array}$ & C-group & CD-group & $P$ value \\
\hline \multicolumn{4}{|l|}{ RI } \\
\hline Child A (12/16) & $\begin{array}{c}0.68 \pm 0.04 \\
0.7(0.6: 0.7)\end{array}$ & $\begin{array}{c}0.72 \pm 0.01 \\
0.72(0.7: 0.74)\end{array}$ & 0.02 \\
\hline Child B (8/8) & $\begin{array}{c}0.70 \pm 0.03 \\
0.71(0.67: 0.73)\end{array}$ & $\begin{array}{c}0.76 \pm 0.02 \\
0.77(0.73: 0.77)\end{array}$ & 0.01 \\
\hline Child C (10/6) & $\begin{array}{c}0.72 \pm 0.04 \\
0.71(0.69: 0.78)\end{array}$ & $\begin{array}{c}0.75 \pm 0.02 \\
0.76(0.72: 0.76)\end{array}$ & 0.02 \\
\hline \multicolumn{4}{|c|}{ (1) } \\
\hline Child A (12/16) & $\begin{array}{c}1.43 \pm 0.07 \\
1.43(1.33: 1.54) \\
\end{array}$ & $\begin{array}{c}1.53 \pm 0.05 \\
1.55(1.42: 1.56) \\
\end{array}$ & 0.007 \\
\hline Child B (8/8) & $\begin{array}{c}1.47 \pm 0.11 \\
1.5(1.31: 1.55)\end{array}$ & $\begin{array}{c}1.57 \pm 0.01 \\
1.57(1.55: 1.58)\end{array}$ & 0.03 \\
\hline Child C (10/6) & $\begin{array}{c}1.52 \pm 0.10 \\
1.56(1.35: 1.59)\end{array}$ & $\begin{array}{c}1.58 \pm 0.006 \\
1.58(1.57: 1.58)\end{array}$ & 0.03 \\
\hline
\end{tabular}

RI (resistance index), P I(pulsatility index)

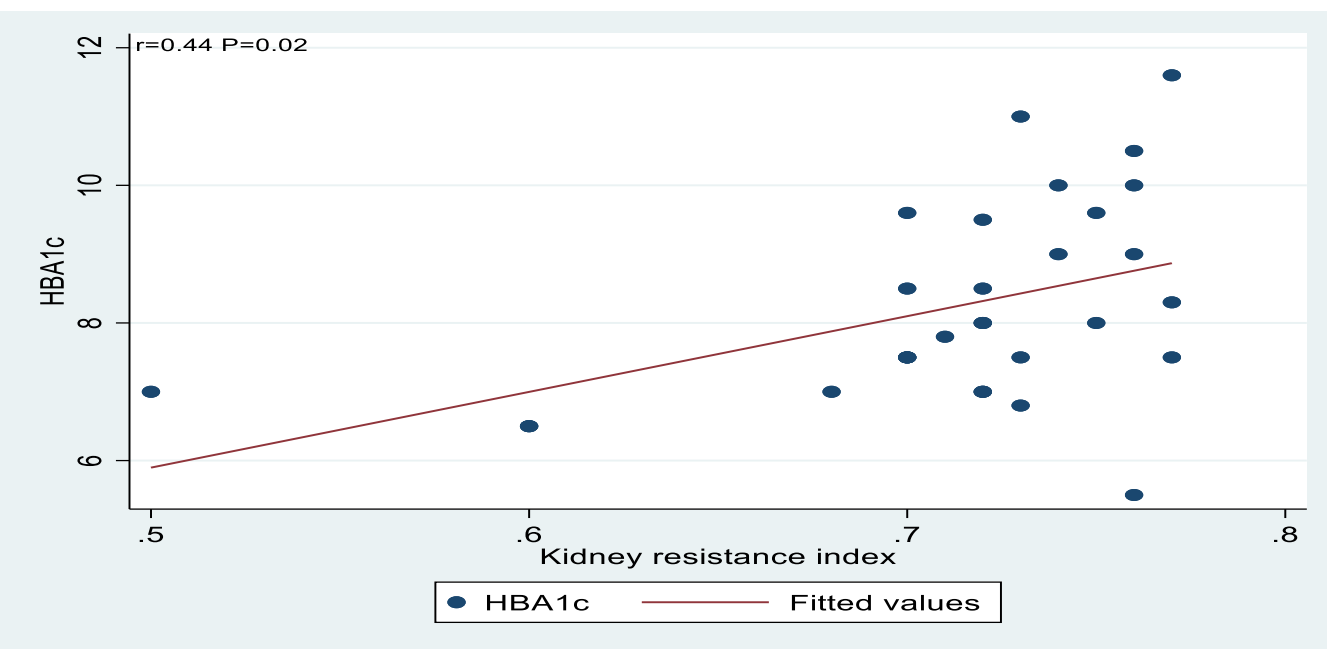

(Figure 1):-Correlation between RI and HbA1c

Alb/Creat ratio had a moderate positive association with PI, and there was a weak positive link between (HbA1c, INR, age), PI, and albumin had a weak negative correlation with PI(figure2-3) 


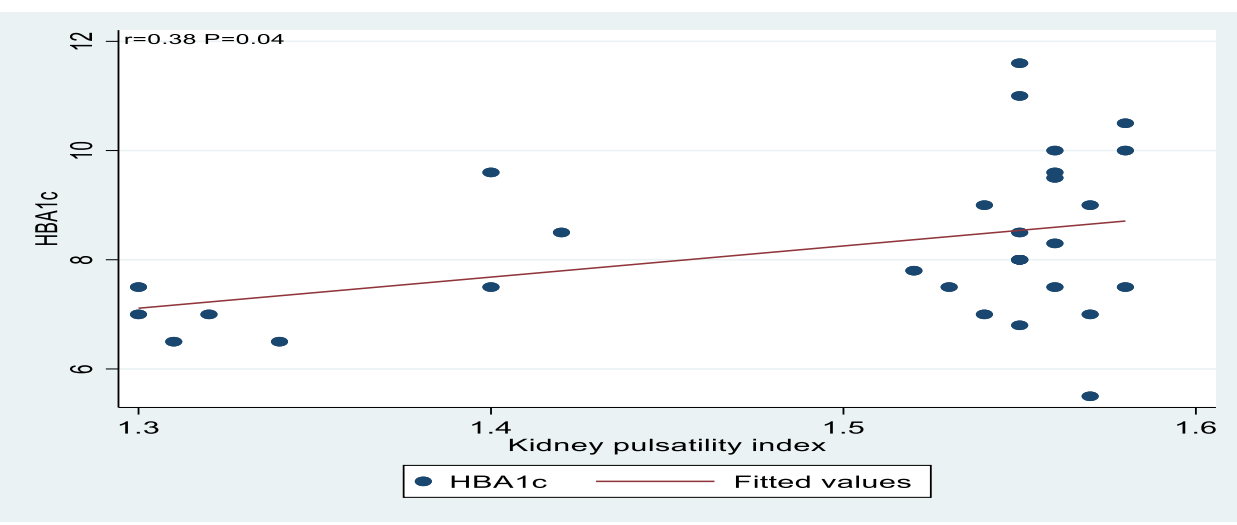

(Figure 2):-Correlation between PI and HbA1c

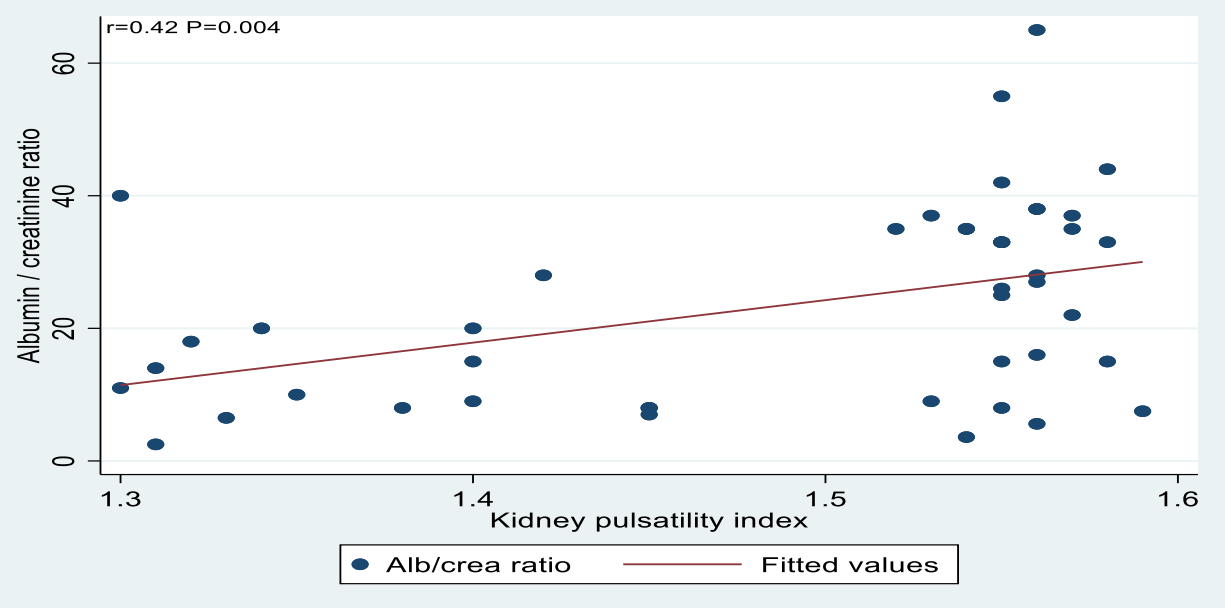

Figure3):-Correlation between PI and Albumin/ creatinine ratio

The RI was found to be substantially linked with HbA1c and INR $(r=0.02$ with $\mathrm{p}=0.02$ and $\mathrm{r}$ $=0.04$ with $p=0.03$, respectively) in a univariate regression analysis.

Age and HbAlc were also linked with PI $(r=0.004$ with $\mathrm{p}=0.03$ and $r=0.03$ with $\mathrm{p}=0.04$, respectively). The PI was also shown to be linked with the albumin/creatinine ratio and INR $(\mathrm{r}=0.003$ with $\mathrm{p}=0.004$ and $\mathrm{r}=0.09$ with $\mathrm{p}=0.01$ respectively).

\section{Discussion}

The RI was higher in the CD-Group and D-Group patients than in the CGroup patients in this study $(0.75 \pm 0.03$ vs. $072 \pm 0.06$ vs. $0.69 \pm 0.04)$. (p-<value0.01). The CD and D groups had considerably higher $\mathrm{PI}$ than the $\mathrm{C}$ group $(1.37 \pm 0.24$ vs. $1.55 \pm 0.04$ vs. 1 . $47 \pm 0.09 v$ vs $1.45 \pm 0.11)$ (p-value $<0.01)$. In Spadaro et al., 2015. (13). In comparison to the C-Group, the CD and DGroups had much higher PI. (1.37 \pm 0.24 vs. $1.38 \pm 0.25$ vs. $1.21 \pm 0.16)$, as compared to the C-Group. Patients in the $\mathrm{CD}$ and $\mathrm{D}$ groups had a greater RI than those in the $\mathrm{C}$ group $(0.73 \pm 0.07$ vs. $0.71 \pm 0.05$ vs. $0.67 \pm 0.07)$. The current study found that (Child-Pugh Classes B and C) had significantly higher resistance index and pulsatility index (RI \&PI) values than (Child-Pugh Class A), regardless of whether the patients had diabetes. the seriousness of the liver illness between the C-Group and the CD-Group, as judged by the Child-Pugh and MELD scores, was not significantly different. Patients in Child-Pugh Class A (1.48 \pm 0.08$)$ had a significantly lower PI than those in Class

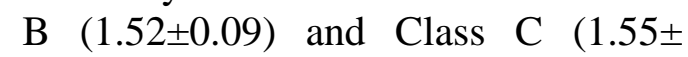
0.04). The RIs had similar outcomes 
(Child A $=0.69 \pm 0.03$, Child $\mathrm{B}=0.72 \pm$ 0.04 , and Child $\mathrm{C}=0.75 \pm 0.02 ; \mathrm{p}<0.05$ ) and similarly, this was in agreement with Spadaro et al (9), In Child-Pugh Class A patients $(1.22 \pm 0.04)$, the PI was substantially lower $(\mathrm{p}=0.05)$ than in Class B $(1.31 \pm 0.05)$ and Class C (1.34 \pm 0.04$)$ patients. Similar results were found in the RI (Child $\mathrm{A}=0.67$ 0.01 ; Child $\mathrm{B}=0.70 \pm 0.01$; and Child $\mathrm{C}=0.73 \pm 0.02 ; \mathrm{p}=0.05)$. Our findings suggest that the presence of diabetes may lead to an elevation in renal Doppler indices in patients with cirrhosis (RI \& PI $0.75 \pm 0.03 \& 1.55 \pm 0.04$ in the CD- group) vs (RI \& PI $0.69 \pm 0$. $04 \& 1.45 \pm 0.11$ in the $\mathrm{C}$ - group), regardless of the severity of liver disease as assessed by the Child-Pugh scoring system, These findings are similar to those of Spadaro et al. as The PIs of the $\mathrm{CD}$ and $\mathrm{D}$ groups were considerably higher than those of the $\mathrm{C}$ group $(1.37 \pm 0.24$ vs. $1.38 \pm 0.25$ vs. $1.21 \pm$ 0.16). Patients in the CD- and DGroups had greater RIs than those in the C-Group. $(0.73 \pm 0.07$ vs. $0.71 \pm$ 0.05 vs. $0.67 \pm 0.07$ ), respectively. $(13,14)$. A statistically significant positive connection was discovered in this study between renal duplex indicators RI and $\mathrm{HbAlc}$ and albumin /creatinine ratio $(\mathrm{r}=0.44, \mathrm{p}$-value 0.02 and $\mathrm{r}=0.40$, p-value 0.007 ) respectively and PI with age ,HbA1cand albumin / creatinine ratio( $\mathrm{r}=0.32 \mathrm{p}$-value $0.03, r=0.38 \mathrm{p}$-value 0.04 and $\mathrm{r}=0.42 \mathrm{p}$ value 0.004 ), and similarly in Abdelhamid et al. On the one hand, renal duplex indicators represented by RI and $\mathrm{Alb} / \mathrm{CR}$, on the other hand, showed a strong independent statistically significant association., $(r=0.6 P<$ 0.001 ) and On the one side, there's PI, and on the other, there's Alb/CR ( $\mathrm{r}=$ $0.6, \mathrm{p}<0.001)$. (15). In our research, univariate regression analysis demonstrated that the PI was linked with age, $\mathrm{HbA1c}$, and the albumin/creatinine ratio $(r=0.004$ with $p=0.03$ and $r=0.03$ with $\mathrm{p}=0.04$ and $\mathrm{r}=0.003$ with $\mathrm{p}$ $=0.004$ respectively ) $\mathrm{HbA} 1 \mathrm{c}$ and INR were both linked to RI. ( $\mathrm{r}=0.02$ with $\mathrm{p}$ $=0.02$ and $\mathrm{r}=0.04$ with $\mathrm{p}=0.03$ respectively) .similarly to Spadaro et al . The PI and RI were shown to be substantially linked with albumin / createnine ratio( $\mathrm{r}=0.54$ with $\mathrm{p}<0.001$ and $\mathrm{r}$ $=0.47$ with $\mathrm{p}<0.01$, respectively) in a univariate regression analysis. (13). Our findings also revealed the presence of systemic hypertension and macrovascular issues in diabetic cirrhotic patients. We discovered that 16 individuals $(53.33 \%)$ in the CD Group have systemic hypertension., 2 (6.6\%) had ischemic heart disease, similarly, Spadaro et al. have shown in diabetic cirrhotic individuals, systemic hypertension and macrovascular consequences are common. they discovered that in the CD Group, $24.2 \%$ of the patients had arterial hypertension, $6 \%$ had experienced a previous acute coronary syndrome, and one had a history of cerebrovascular illness. (13)

\section{Conclusion}

This study shows that diabetes has a considerable negative impact on the renal health of cirrhotic patients and that it worsens renal vasoconstriction. Diabetes may play a role in the progression of renal failure in liver cirrhosis.

\section{Recommendations}

Based on the results of our study. We recommend using renal Doppler ultrasonography to cirrhotic patients with diabetes with normal kidney function for early detection of renal affection, for proper and early management especially renal Doppler is a non-invasive technique.

\section{Ethical approval}

The study protocol received approval from Sohag university hospital, faculty of medicine. Before collecting data, administrative approval and official 
permissions were acquired. Patients who accept the invitation to take part in the research gave their informed consent after being assured that their data would be kept private. X|PO97T3W1X C

\section{References}

1- Angeli P, Ginès P, Wong F, Bernardi M, Boyer TD, Gerbes A, et al. Diagnosis and management of acute kidney injury in patients with cirrhosis: revised consensus recommendations of the International Club of Ascites. 2015;64(4):531-537.

2- Fede G, D’Amico G, Arvaniti V, Tsochatzis E, Germani G, Georgiadis D, et al. Renal failure and cirrhosis: a systematic review of mortality and prognosis. 2012;56(4):810-818.

3- Huelin P, Piano S, Solà E, Stanco M, Solé C, Moreira R, et al. Validation of a staging system for acute kidney injury in patients with cirrhosis and association with acute-on-chronic liver failure. $2017 ; 15(3): 438-445$.

4- Nadim MK, Kellum JA, Davenport A, Wong F, Davis C, Pannu N, et al. Hepatorenal syndrome: the 8 th international consensus conference of the Acute Dialysis Quality Initiative (ADQI) Group. 2012;16(1):1-17.

5- Schwabl P, Bucsics T, Soucek K, Mandorfer M, Bota S, Blacky A, et al. Risk factors for the development of spontaneous bacterial peritonitis and subsequent mortality in cirrhotic patients with ascites. 2015;35(9):21218.

6- Wong FJNrG, hepatology. The evolving concept of acute kidney injury in patients with cirrhosis. 2015;12(12):711-9.

7- Elkrief L, Rautou PE, Sarin S, Valla D, Paradis V, Moreau RJLI. Diabetes mellitus in patients with cirrhosis: clinical implications and management. 2016;36(7):936-48.
8. Sigal SH, Stanca CM, Kontorinis N, Bodian C, Ryan EJAJoG. Diabetes mellitus is associated with hepatic encephalopathy in patients with $\mathrm{HCV}$ cirrhosis. 2006;101(7):1490-1496.

9- Child III C. Surgery and portal hypertension. Child III CG, editor. The Liver and Portal Hypertension. Philadelphia: Saunders; 1964.

10- Alessandria C, Ozdogan O, Guevara M, Restuccia T, Jiménez W, Arroyo V, et al. MELD score and clinical type predict prognosis in hepatorenal syndrome: relevance to liver transplantation. 2005;41(6):1282-1289.

11- Sumida K, Nadkarni GN, Grams ME, Sang Y, Ballew SH, Coresh J, et al. Conversion of urine protein-creatinine ratio or urine dipstick protein to urine albumin-creatinine ratio for use in chronic kidney disease screening and prognosis: An individual participantbased meta-analysis. 2020;173(6):426435 .

12- Levey AS, Inker LAJCP,
Therapeutics. glomerular filtration rate in health and disease: a state of the art review. 2017;102(3):405-19.

13- Spadaro L, Privitera G, Fede G, Magliocco O, Russello M, Piro S, et al. Diabetes increases renovascular impedance in patients with liver cirrhosis. 2015;10(6):703-9.

14-Popov D, Krasteva R, Ivanova R, Mateva L, Krastev ZJIjon. Doppler parameters of hepatic and renal hemodynamics in patients with liver cirrhosis. 2012;2012.

15- Abdelhamid YM, Fawzy MW, Abd Al-Salam RF, Gouda YM, Salem MMJKAAMJ. Relation between resistivity and pulsatility indices of renal and intrarenal arteries and degree of albuminuria in type 2 diabetic patients. 2017;23(1):1. 